\title{
Integrating the views and perceptions of UK energy professionals in future energy scenarios to inform policymakers
}

\author{
Gareth Parkes $^{\mathrm{a}, *}$, Catalina Spataru \\ ${ }^{\mathrm{a}}$ Energy Institute \\ ${ }^{\mathrm{b}}$ University College London
}

ABSTRACT

\begin{abstract}
The Energy Institute (EI) developed its first Energy Barometer survey in 2015 which aims to understand professionals' views and opinions of energy priorities, policies and technologies. 543 UK energy professionals from across the energy sector were surveyed. Following the survey, $79 \%$ of UK energy professionals believe their sector is not effectively communicating with the public. This suggests there is an urgent need to better understand how to use surveys in a more methodological way. Developed in conjunction with the EI, this paper presents the Energy Barometer survey methodology and results to achieve a better understanding of UK energy professionals' current perceptions and future priorities. The paper makes two contributions to enhance the UK's energy debate. First, it provides the first results in a longitudinal assessment of energy professionals' views of energy policy issues and discusses the implications for future policymaking. Second, it identifies opportunities for Energy Barometer findings to feed into scenarios development. A comparison with other studies was undertaken. It has been shown that the views of professionals working across the sector are aligned with decentralised approaches to decarbonisation. In particular, professionals expect action from policymakers to coordinate, engage with and encourage investment in energy efficiency.
\end{abstract}

\section{I - Introduction}

In 2008, the UK established a policy imperative to transition to a sustainable economy based on low carbon energy. The Climate Change Act (2008) sets out the UK's ambitious targets, recognising the need for significant change to the energy system. This frames the subsequent debate, which considers how to achieve the transition securely, affordably and sustainably.

To inform debate, energy systems models depict a range of potential scenarios. Such models investigate the inevitable pressures and trade-offs that exist between different stakeholders, and the results provide plausible evidence upon which to make policy and business decisions. A challenge for decision makers is to ensure the changes taking place to the energy system are accepted and to foster coopera- tion of the multifarious stakeholders to make that change a reality (HM Government, 2011).

Foxon's (2013) pathway scenarios, as with most scenario studies (Parkhill et al., 2013; Balta-Ozkan et al., 2014; Spataru et al., 2015; Butler et al., 2015), use the targets imposed on the UK through the Climate Change Act (2008). Their analyses incorporate the insights of expert panels, stakeholder workshops or Delphi studies to improve their accuracy and reduce uncertainty. This paper considers opportu- nities for use of energy barometers and the importance of integration of professionals' views and perceptions in future energy scenarios.

The professionals working across the energy sector are one sub- category of an amorphous public. In this paper, we discuss how energy professionals' views can further aid policymakers and contribute to refinement of the direction of future energy system change (Foxon, 2013; Butler et al., 2015; Spataru 
et al., 2015), particularly by assisting the characterisation of investment risk and uncertainty (Watson et al., 2014).

\subsection{UK energy policy trilemma}

The combined energy security, affordability and sustainability challenges are known in the UK as the energy trilemma (E.ON UK, 2008). Parkhill et al. (2013) suggest the three challenges are in fact a meta-narrative, intricately related to public values and preferences for energy system change. They conclude changes are only likely to be accepted when in alignment with such values. West et al. (2010) advocate for a "more detailed qualitative investigation, informed by social and psychological theory" that goes beyond identification of public opinion, as a single entity. Kearnes and Wynne (2007) validate this approach, stressing the importance of interpreting expert assess- ments, not as objective and value-free, but rather as subjective and value-based.

Table 1: Electricity generation technology uncertainties, from Watson et al. (2014)

\begin{tabular}{|c|c|c|c|}
\hline & Techno-Economic & Programme & System Integration \\
\hline Generic & $\begin{array}{l}\text { - Economic \& financial } \\
\text { viability } \\
\text { - Uncertainty over future } \\
\text { costs } \\
\text { - Market conditions (e.g. } \\
\text { future demand and fuel } \\
\text { prices) }\end{array}$ & $\begin{array}{l}\text { - Policy commitment and } \\
\text { support } \\
\text { - Public acceptance } \\
\text { - Supply-chains for scaling- } \\
\text { up } \\
\text { - Skills \& knowledge } \\
\text { - Innovation co-ordination }\end{array}$ & $\begin{array}{l}\text { - Achieving high levels of } \\
\text { electricity system diversity } \\
\text { - Adapting supply-side } \\
\text { options to demand-side } \\
\text { flexibility and innovation }\end{array}$ \\
\hline Nuclear & $\begin{array}{l}\text { - High capital costs \& } \\
\text { realising reductions } \\
\text { - Long-term waste } \\
\text { management } \\
\text { - Long build times }\end{array}$ & $\begin{array}{l}\text { - Long-term waste } \\
\text { management } \\
\text { - Regulatory risks } \\
\text { associated with safety } \\
\text { requirements }\end{array}$ & $\begin{array}{l}\text { - Adapting to changing } \\
\text { base-load profile of supply }\end{array}$ \\
\hline CCS & $\begin{array}{l}\text { - Realising cost reductions } \\
\text { - Regulation of CO2 storage } \\
\text { - Integration of CCS } \\
\text { component systems and } \\
\text { skills }\end{array}$ & $\begin{array}{l}\text { - Variety of technologies } \\
\text { could fragment } \\
\text { development efforts } \\
\text { - Scaling-up technology } \\
\text { - Realising cost reductions }\end{array}$ & $\begin{array}{l}\text { - Operating } \mathrm{CO}_{2} \text { transport } \\
\text { \& storage under variable } \\
\text { generation profile }\end{array}$ \\
\hline $\begin{array}{l}\text { Offshore } \\
\text { Wind }\end{array}$ & $\begin{array}{l}\text { - Realising cost reductions } \\
\text { (capital \& operating costs) }\end{array}$ & $\begin{array}{l}\text { - Uncertainty over domestic } \\
\text { supply chain }\end{array}$ & \multirow{2}{*}{$\begin{array}{l}\text { - Integration of intermittent } \\
\text { generation: need for } \\
\text { storage, demand-side } \\
\text { response, interconnection } \\
\text { etc. }\end{array}$} \\
\hline Solar PV & $\begin{array}{l}\text { - Potential volatility of } \\
\text { international supply chain } \\
\text { costs }\end{array}$ & $\begin{array}{l}\text { - Creating stable price } \\
\text { support expectations }\end{array}$ & \\
\hline
\end{tabular}

\subsection{Investment risk and uncertainty}

The energy system is under pressure to adapt to increasing proportions of intermittent or flexible supply, such as wind and solar. As flexibility increases, so does the uncertainty due to the pathdependency costs caused by the long life-cycles of energy infrastructure (Usher and Strachan, 2012). Blyth et al. (2015), reviewing the power sector, demonstrate it is unclear whether the levels of investment obtained in recent years can be maintained or increased post-2020, further increasing uncertainty. Table 1 shows how Watson et al. (2014) classify electricity generation technology uncertainties, potentially leading to delayed or withheld investment, across different levels of the energy system. A primary conclusion of their work is the role public attitudes can play in reducing uncertainty and the need to engage people and communities more closely with the UK transition to a low carbon economy. The development of the energy barometer approach presented in this paper provides a new mechanism for engagement and dialogue.

\section{Energy Barometers}

Energy professionals are a useful subset of the actor groups presented by Foxon (2013). Whitmarsh (2011) supposes that "lay- expert disparity in perceptions is less likely to be a function of educational or knowledge deficit than of ideological variation between individuals". It is therefore unlikely the 
views of energy professionals are representative of wider public views. However, the use of exploratory qualitative interviews and explanatory quantitative questionnaires can contribute to energy system discourse and lead to more considered perspectives of future energy systems. We aim to enable comparisons of their perceptions, which may also work to reduce the psychological distance of the public from climate change issues, a major policy and research objective (Capstick et al., 2015).

A number of other energy barometers and surveys exist, although there is not comprehensive and regular coverage of the whole sector. A selection of these surveys and reports are shown in Table 2:

\subsection{Choice of research design}

To collect people's views, it is often suggested there is a sliding scale of methodologies available to undertake social surveys, ranging between qualitative, detailed and unstructured interviews, and quantita- tive closed-response questionnaires (Morgan, 2007). Mixed methods, employing a combination of different approaches, either sequentially or concurrently, are also common (Saunders et al., 2012). Fig. 1 presents a schematic of the different methods available.

De Vaus (2002) points out surveys can take several different forms, the central premise being that by asking a sample population the same questions, it is possible to identify trends and patterns. To ensure meaningful distribution of results requires correct sampling of data (Saunders et al., 2012). Gill and Johnson (2010) advocate the devel- opment of a structure that, for specific research questions, can be empirically tested with a methodology that facilitates replication and ensures reliability.

For this paper, the requirement to consider the wider context and future replicability and representation across energy professionals, mean a significant need for external validation. The threshold for this validity is more difficult to achieve with qualitative research (Saunders et al., 2012), through which we arrive at a concurrent embedded design which asks some qualitative questions within a predominantly quanti- tative questionnaire. This solution applies Grounded Theory (Charmaz and Smith, 2010) to qualitative questions and responses, supporting the dominant quantitative survey strategy.

\subsection{Research design}

A suitable sample frame from a suitable population must answer appropriate questions, with their responses analysed (Saunders et al., 2012). As the professional membership organisation for the energy sector, with 23,000 members globally, the Energy Institute (EI) is well placed to provide a sample frame. These are professional members with at least four years' work experience in the energy sector or who have completed a degree in an energy-related subject. All members are required to maintain continuous professional development to maintain their membership. This mechanism enables confidence in the contin- ued expertise and relevance of the sample population over time.

Historically, EI members have been engineers from oil and gas and energy demand backgrounds, however this has shifted significantly in recent years to encompass many more economists, policy advisors, environmentalists and other energy-related professions. Demographics data collected from survey respondents shows their expertise in many disciplines, with many members having experience of more than one area. A summary of the top categories, based on self-selection is shown in Fig. 2.

\subsubsection{EI College formulation}

In January 2015, there were approximately 13,000 EI members in the UK. A sample selected from this group ensures the level of knowledge and understanding of energy issues remains high. To deliver statistically significant results requires a probabilistic sampling ap- proach (Saunders et al., 2012). De Vaus (2002) recommends a simple random sampling approach. Saunders et al. (2012) highlight the importance of sample selection ethics when defining the population and sampling method. All professionals and those likely to become professionals in future formed the population for 
this study.

The expectation to continue this research on an annual basis lead to the introduction of a 'college' of EI members, based on the EPSRC College (EPSRC, 2015). A critical factor in this creation was to overcome the challenge of low participation rates to online surveys, achieved through eliciting a commitment from members, and with a demonstrably positive influence on actor behaviour (Pollitt and Shaorshadze, 2011). The randomisation of invitations also helped to reduce self-selection bias (De Vaus, 2002).

Non-response was considered from the perspective of reduced sample size and bias. By following the good practice for survey response collection advocated by Fink (2013) and drawing a conserva- tive sample size, this risk was mitigated. The differences between three different grades of EI membership (Fellow, Member and Graduate) were also factored into the sample framing calculations to ensure experience is valued and that all grades are well represented. Table 3 summarises the numbers of invitations sent, with 543 College partici- pants completing the survey, set against the minimum requirement of 380 (Saunders et al., 2012, Table 7.1).

Inviting less than 1 in 3 members to join this first EI College ensures, in later years, there will be a sizeable population from which to draw. This will be further extended by replacing up to $50 \%$ of the College each year. This panel design ensures a level of continuity, and should produce higher quality results (Groves et al., 2009).

\subsubsection{Energy Barometer questionnaire formulation}

Response rates can be maximised through a clear, concise intro- duction and precise, objective questions (Fink, 2013). Significant effort was given to the questionnaire development, as recommended by De Vaus (2002), to ensure data reliability and validity. The number of questions is critical to ensuring high response rates, with longer surveys completed by fewer respondents (De Vaus, 2002). An advisory panel were used to develop question themes and as a pilot group to provide insight into question suitability, as recommended by Saunders et al. (2012). The questions were reviewed by specialists (from Cardiff University's Understanding Risk Research Group, selected for their survey expertise) following industry good practice (Saunders et al., 2012). This increased question precision and simplified the language used.

All respondents were given the same amount of time to complete the survey; this was initially set at two weeks, and subsequently extended for an additional two weeks.

Considerable effort was expended to ensure the questions them- selves were clear, unambiguous, useful, and appropriately grouped (De Vaus, 2002, Chapter 7). The survey was cross-sectional in design, developed to enable repetition in future (De Vaus, 2002). Opinion and knowledge-based questions were the focus of the survey, with attribute variables, such as gender, profession, sector of work, collected to facilitate analysis, following good practice (Saunders et al., 2012). To ensure consistency in the results, questions were predominantly closed quantitative questions (De Vaus, 2002; Fink, 2013), although optional open text qualitative questions were also posed, to elicit additional detail around particular subjects, following the EI's pragmatic ap- proach (Morgan, 2007). These included a mix of single-balanced and multiple-response categories (Tharenou et al., 2007, cited in Saunders et al., 2012 Table 11.3).

The usefulness, potential and ability to be analysed were considered during the survey design stage. Interval data was used where possible, as increasing levels of variable measurement enable a greater range of analytical tools to be applied (De Vaus, 2002). This was combined with ordinal data for responses to opinion- and knowledge-based questions. In total, 33 quantitative, 13 qualitative and 14 demographics and knowledgeability questions were asked, ensuring comprehensive cover- age of several areas of the energy sector, including policy, investment, innovation, climate change, skills, public engagement and efficiency. 
Figure 1: Methodological choice (Adapted from Saunders et al., 2012)

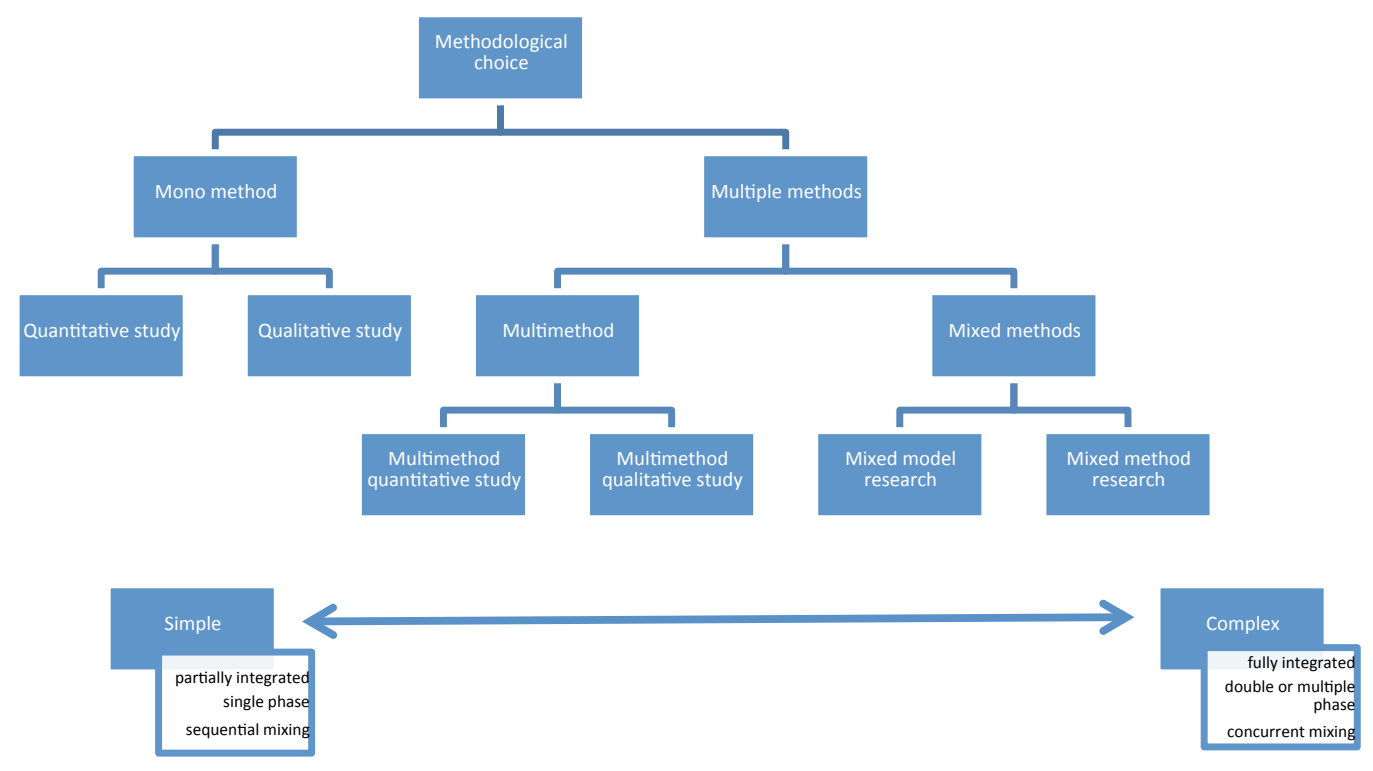

A summary of the differences of this approach, compared to previous approaches is presented in Table 4. The key novelties are the:

- development of a representative survey of a clearly defined population of experts.

- ability to monitor expertise in the sample population over time, in

compliance with professional engineering institute standards introduction of commitment to

ensure high-levels of participation

- $\quad$ subsequent opportunity to ask a high number of extensive questions

- potential to develop longitudinal results, whilst maintaining high response rates

- 3. Results and key messages This section presents results from the EI's Energy Barometer survey 2015 (EI, 2015). Section 3.1 considers 2015's biggest challenges, foreseen by energy professionals. Based on these challenges, Section 3.2 considers perceptions of current policy and uncertainty; and

Table 3 - El College specification 


\begin{tabular}{|c|c|c|}
\hline Member grade included & FEI, MEI, GradEI & \\
\hline Population & 13,000 & \\
\hline $\begin{array}{l}\text { Minimum number of members } \\
\text { required }\end{array}$ & 371 & \\
\hline Invitations sent & 3,807 & $29.3 \%$ (of population) \\
\hline Accepted invitation & 857 & $22.5 \%$ (of invitations) \\
\hline Completed survey & 543 & $\begin{array}{l}63.4 \% \text { (of El College } \\
\text { members) }\end{array}$ \\
\hline
\end{tabular}

Section 3.3 examines investment over the next 3 years. 3.1. Ten key messages from energy professionals

EI members reported what they thought the energy industry's biggest challenge was for 2015, and to list any other challenges faced by the industry in 2015 (Fig. 3).

The dominance of energy policy in the results can be linked to the time at which the survey was taken; in the lead up to the 2015 General Election. However, whilst a number of respondents explicitly mentioned the election, the majority either responded in more general terms, or mentioned long-term policy uncertainty.

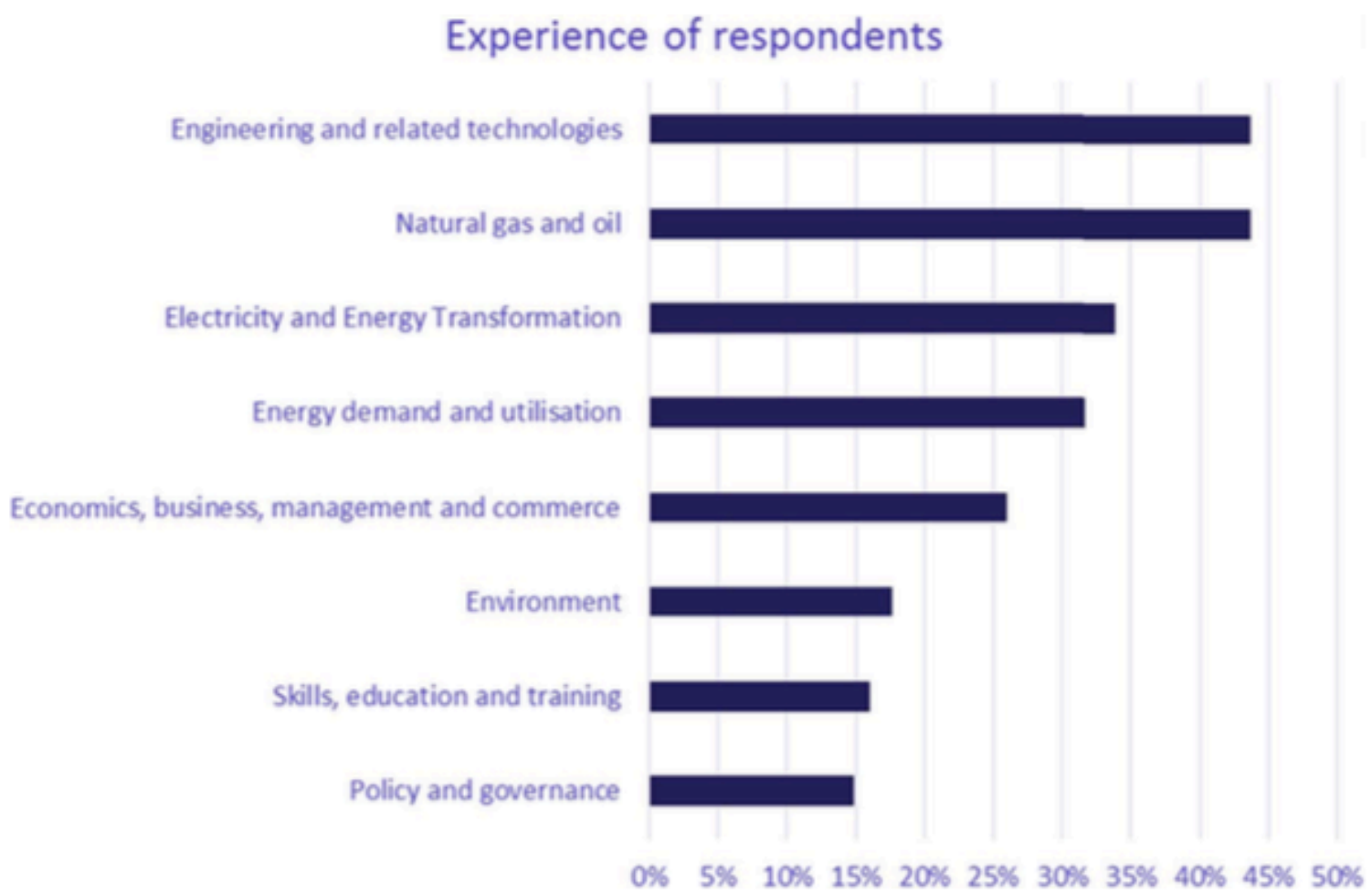

Fig. 2. Member disciplines and areas of work. 
Table 4

Novelty contribution related to previous works.

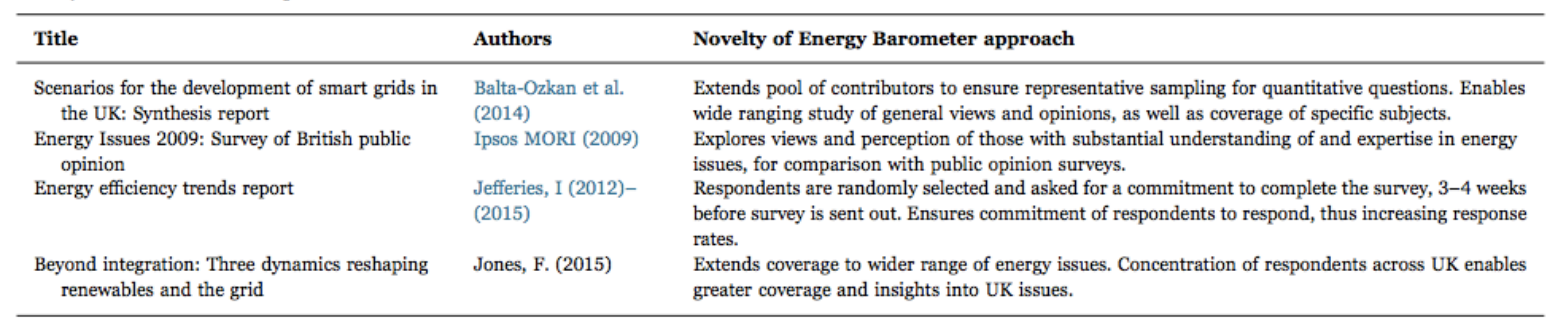

These results, following the embedded design approach (Saunders et al., 2012), provide a frame in which to select and explore other issues more quantitatively. Many respondents highlighted the interconnec- tion between issues with, for example, low oil prices, energy policy and the need for a skilled workforce impacting upon low carbon investment decisions. The next sections of this paper focus on energy policy and investment to better understand energy professionals' views, before considering the potential that such results have to be compared to low carbon scenarios.

\subsection{Energy policy}

To ensure balanced coverage of the issues, analysis addresses energy supply and demand. Low carbon energy supply and energy efficiency have been selected due to their prominence in the top ten issues and role in the energy system, as well as representing opportu- nities for actions that straddle energy security, sustainability and affordability priorities.

\subsubsection{Policy effectivenessRespondents were asked whether they felt energy policies were}

effective, ineffective, or counterproductive towards their most impor- tant energy trilemma challenge $(\mathrm{N}=543)$. Table 5 shows the list of energy efficiency policies, their stated aim and when they were introduced. Table 6 shows low carbon energy supply policies. Figs. 4 and 5 show respondents answers for individual policies. A net effectiveness score has been calculated by subtracting the 'ineffective' and 'counterproductive' from 'effective' responses. This summarises perceived effectiveness of energy policies from sustainability, energy security and affordability perspectives.

Results suggest building regulations are seen as effective across affordability, security and sustainability priorities. There is a general trend towards more recently introduced energy efficiency policies being seen as less effective across all priority areas. The Department of Energy and Climate Change (DECC, 2012) suggest four categories of barriers to energy efficiency implementation: the small size of markets, the lack of access to trusted information, misaligned financial incen tives and an undervaluing of energy efficiency. Anecdotal evidence and open responses from energy professionals suggest that frustration of policies to address these issues, combined with rising energy costs is a negative effect on perceived policy effectiveness as new policies are introduced. This is supported by evidence from the now halted Green Deal, with Shankleman (2015), reporting its early troubled reputation was difficult to shake off. The new Energy Savings Opportunity Scheme (ESOS) appears to reverse this trend; however, this could be due to professionals waiting for it to pass its first significant milestone at the end of 2015 before making up their minds.

Another explanation for this trend is the type of policy being implemented, with market-based measures being seen as inferior to regulation and obligations for home energy efficiency measures (Turner, 2011). This explanation accounts for ESOS being seen as both a new and effective policy. By repeating the survey in 2016, it will be possible to examine changes in perception of this policy.

The trend in perception of low carbon energy supply policies is very different to energy efficiency policies. The implication, with the exception of Electricity Market Reform (EMR), is energy supply policies are perceived as more effective the more recently they have been implemented. This trend is evident across security, affordability and sustainability priorities. EMR was further investigated 
within the Energy Barometer; with respondents suggesting its complexity has made it difficult to understand, but ultimately it will act as a catalyst for low carbon investment, with the Feed-in Tariff being the particularly effective element (EI, 2015). The diverse policy selection may also impact upon the trend evident for low carbon energy supply policies, with policies covering a wider range of applications and sectors than for energy efficiency.

A comparison of the general trends in these policy groupings, suggests development of policy mechanisms for energy supply and demand are on two very different trajectories. Such perception can provide additional insight to assist in the extension of existing policy and development of new policy, with energy professionals perceiving energy efficiency policy to be in greater need of attention. There is the potential for such results to influence the policy uncertainty criteria for scenario building, for example the regulation of buildings as a measure to improve building energy efficiency, enabling more progressive tightening of this policy and reducing associated uncertainty in scenario development.

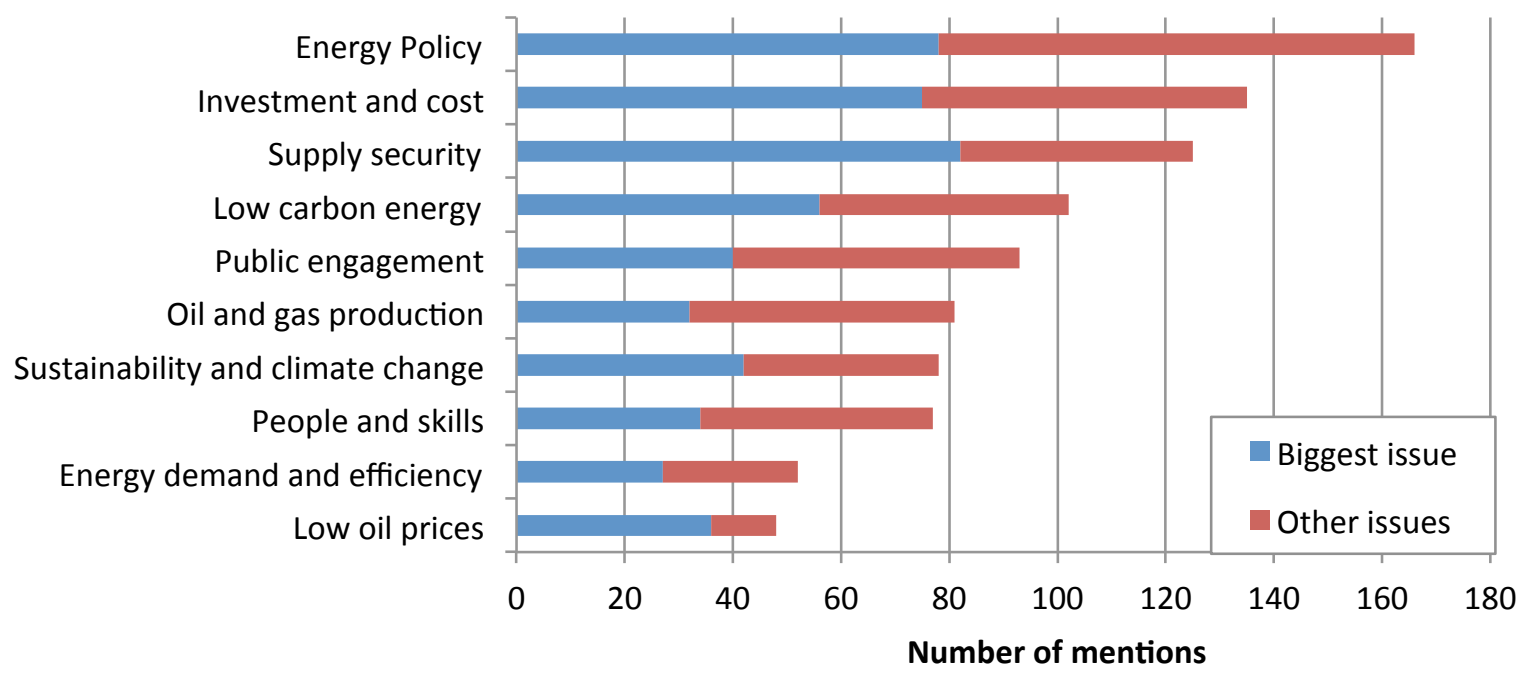

Fig. 3. Energy Professionals Top 10 Challenges in 2015. 


\begin{tabular}{|c|c|c|c|c|}
\hline Policy & Stated aim & When introduced & $\begin{array}{l}\text { Type of } \\
\text { measure }\end{array}$ & $\begin{array}{l}\text { Energy supply } \\
\text { / Energy } \\
\text { efficiency }\end{array}$ \\
\hline $\begin{array}{l}\text { Building Regulations (Part } \\
\text { L: Conservation of fuel } \\
\text { and power) }\end{array}$ & $\begin{array}{l}\text { Sets out energy efficiency } \\
\text { requirements of buildings }\end{array}$ & $\begin{array}{l}\text { Originally introduced as } \\
\text { part of Building Act } 1984, \\
\text { regularly amended since. }\end{array}$ & $\begin{array}{l}\text { Standards and } \\
\text { Regulation }\end{array}$ & $\begin{array}{l}\text { Energy } \\
\text { efficiency } \\
\text { policy }\end{array}$ \\
\hline $\begin{array}{l}\text { Climate Change } \\
\text { Agreements }\end{array}$ & $\begin{array}{l}\text { Voluntary agreements that allow } \\
\text { eligible energy intensive sectors to } \\
\text { receive reductions in the CCL if they } \\
\text { sign up to energy efficiency targets }\end{array}$ & 2000 & $\begin{array}{l}\text { Economic } \\
\text { instrument }\end{array}$ & $\begin{array}{l}\text { Energy } \\
\text { efficiency } \\
\text { policy }\end{array}$ \\
\hline $\begin{array}{l}\text { Code for Sustainable } \\
\text { Homes }\end{array}$ & $\begin{array}{c}\text { National standard for sustainable } \\
\text { design and construction of new homes } \\
\text { for energy and water use }\end{array}$ & 2006 & $\begin{array}{l}\text { Voluntary } \\
\text { measure }\end{array}$ & $\begin{array}{c}\text { Energy } \\
\text { efficiency } \\
\text { policy } \\
\end{array}$ \\
\hline $\begin{array}{l}\text { Carbon Reduction } \\
\text { Commitment Energy } \\
\text { Efficiency Scheme }\end{array}$ & $\begin{array}{l}\text { Mandatory reporting and pricing } \\
\text { scheme to improve energy efficiency in } \\
\text { large public and private organisations }\end{array}$ & 2010 & $\begin{array}{l}\text { Economic } \\
\text { instrument }\end{array}$ & $\begin{array}{l}\text { Energy } \\
\text { efficiency } \\
\text { policy }\end{array}$ \\
\hline Green Deal & $\begin{array}{l}\text { Provides assistance to make energy- } \\
\text { saving improvements to homes }\end{array}$ & 2012 & $\begin{array}{l}\text { Economic } \\
\text { instrument }\end{array}$ & $\begin{array}{l}\text { Energy } \\
\text { efficiency } \\
\text { policy }\end{array}$ \\
\hline $\begin{array}{c}\text { Energy Savings } \\
\text { Opportunity Scheme } \\
\text { (ESOS) }\end{array}$ & $\begin{array}{c}\text { Requirement for large organisations to } \\
\text { undertake an energy audit }\end{array}$ & 2014 & $\begin{array}{l}\text { Mandatory } \\
\text { audit }\end{array}$ & $\begin{array}{l}\text { Energy } \\
\text { efficiency } \\
\text { policy }\end{array}$ \\
\hline
\end{tabular}

Building Regulations (Part L: Conservation of fuel and power)

Climate Change Agreements

Code for Sustainable Homes

Carbon Reduction Commitment Energy Efficiency Scheme

Green Deal

Energy Savings Opportunity Scheme (ESOS)

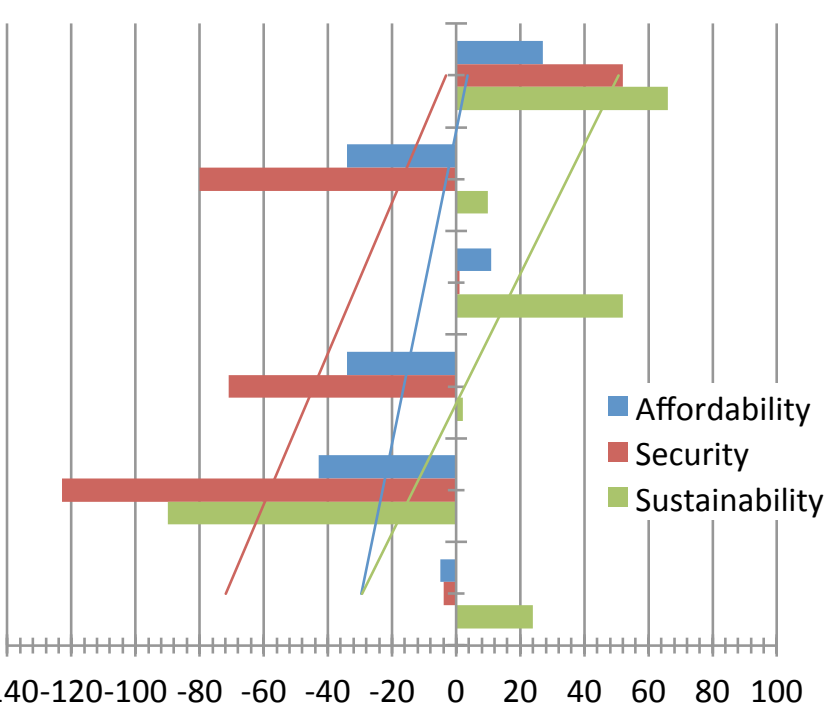

Less Effective Net Efficacy More Effective

Fig. 4. Energy efficiency policy net efficacy by Trilemma priority.

Table 6: UK low carbon energy supply policies 


\begin{tabular}{|c|c|c|c|c|}
\hline Policy & Stated aim & When introduced & $\begin{array}{l}\text { Type of } \\
\text { measure }\end{array}$ & $\begin{array}{c}\text { Energy supply } \\
\text { / Energy } \\
\text { efficiency }\end{array}$ \\
\hline Climate Change Levy & $\begin{array}{c}\text { Tax on energy delivered to non- } \\
\text { domestic users to reduce carbon } \\
\text { emissions }\end{array}$ & 2000 & $\begin{array}{l}\text { Economic } \\
\text { instrument }\end{array}$ & $\begin{array}{l}\text { Low carbon } \\
\text { energy } \\
\text { supply policy }\end{array}$ \\
\hline $\begin{array}{l}\text { Renewable Transport } \\
\text { Fuels Obligation }\end{array}$ & $\begin{array}{l}\text { Requirement on transport fuel } \\
\text { suppliers to ensure a percentage of } \\
\text { road vehicle fuel is supplied from } \\
\text { renewable sources }\end{array}$ & 2005 & $\begin{array}{l}\text { Standards and } \\
\text { Regulation }\end{array}$ & $\begin{array}{l}\text { Low carbon } \\
\text { energy } \\
\text { supply policy }\end{array}$ \\
\hline $\begin{array}{l}\text { Renewable Heat } \\
\text { Incentive }\end{array}$ & $\begin{array}{l}\text { Payment for generation of renewable } \\
\text { heat }\end{array}$ & 2011 & $\begin{array}{l}\text { Economic } \\
\text { instrument }\end{array}$ & $\begin{array}{l}\text { Low carbon } \\
\text { energy } \\
\text { supply policy }\end{array}$ \\
\hline Electricity Market Reform & $\begin{array}{c}\text { Incentivise investment in secure, low- } \\
\text { carbon electricity, improve electricity } \\
\text { supply and improve affordability for } \\
\text { consumers }\end{array}$ & 2013 & $\begin{array}{l}\text { Economic } \\
\text { instrument }\end{array}$ & $\begin{array}{l}\text { Low carbon } \\
\text { energy } \\
\text { supply policy }\end{array}$ \\
\hline
\end{tabular}

Figure 4: Low carbon energy supply policy net efficacy by Trilemma priority

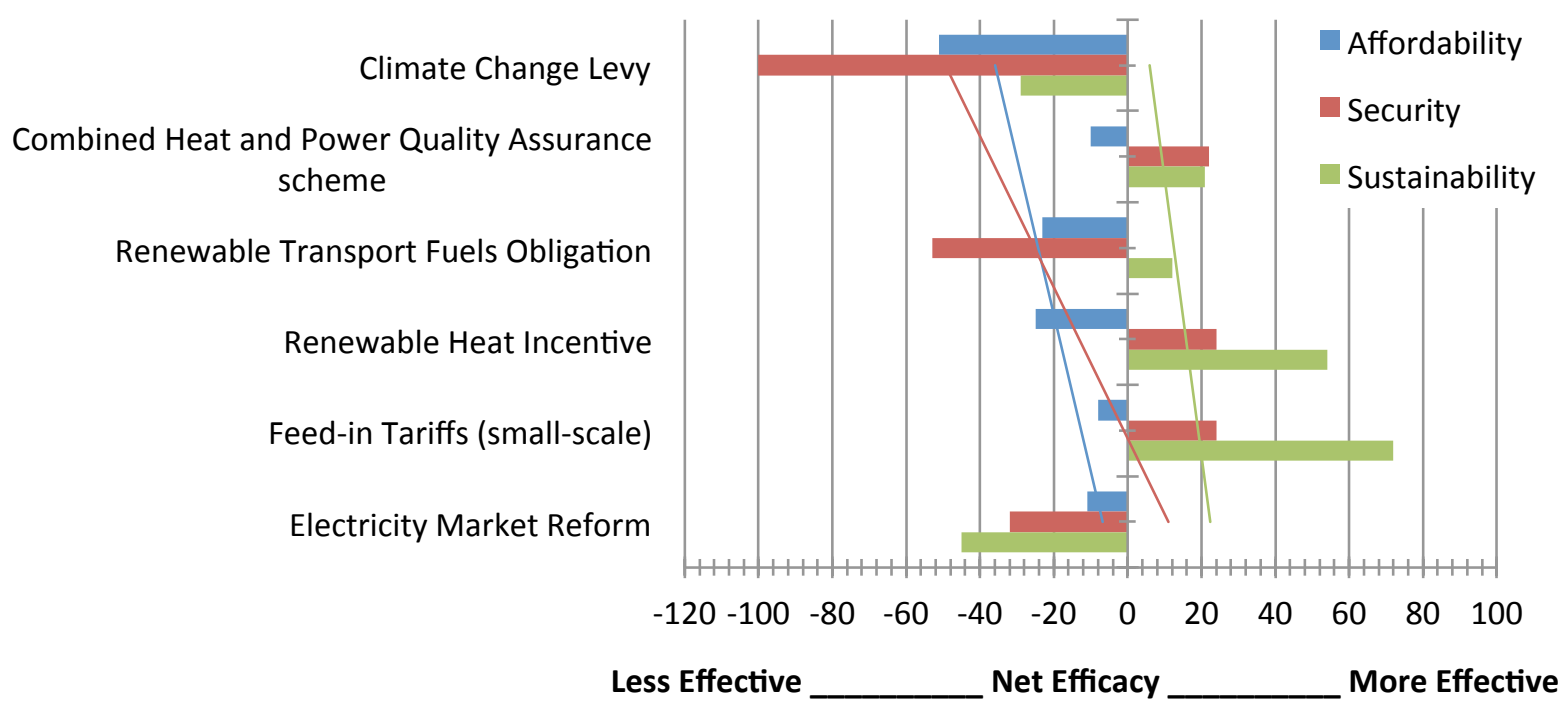

\subsubsection{Investment risk and policy uncertainty}

To consider the impact policy uncertainty has on low carbon technologies, EI members were asked whether investment risk due to policy uncertainty has changed in the last 12 months. Fig. 6 shows the changes to risk over the previous year for each technology, with low carbon supply technologies perceived to be more uncertain, and only energy efficiencies being in a moderately better position. The differ- ences in certainty continue to suggest differences in the way supply- and demand-side measures are perceived by energy professionals. Interestingly, when considered with policy effectiveness, this suggests energy efficiency is an area of investment potential, in-spite of ineffective government policy. This may be as a result of supply-side investment being perceived to be of greater 
risk, leading investors to reconsider energy efficiency measures. These results have the potential to inform technology pathways for scenario development, by indicating the technologies seen as most likely to receive industry support.

\subsection{UK investment risk}

Fig. 7 demonstrates professionals' opinions regarding changes to investment levels across the energy sector. EI members were asked whether the level of investment for these areas should increase, stay the same, or decrease, over the next 3 years. The sectors receiving most support for increased investment were efficiency-related, which sub- stantiates previous results. Such results have implications for govern- ment and industry priorities, as well as lending weight to different sectors for short term prioritisation within pathway development. The strong implication, underpinned by Section 3.2.1, is that professionals working across the sector think government and industry should be prioritising energy efficiency.

demand-side measures are perceived by energy professionals. Interestingly, when considered with policy effectiveness, this suggests that energy efficiency is an area of investment potential, in-spite of ineffective government policy. This may be as a result of supply-side investment being perceived to be of greater risk, leading investors to reconsider energy efficiency measures. These results have the potential to inform technology pathways for scenario development, by indicating the technologies seen as most likely to receive industry support.

Comparison with the results from other studies helps to lend weight to the credibility of this study and identifies opportunities to integrate its findings with scenario studies. A selection of studies demonstrates areas in which Energy Barometer results support or enhance under- standing and provide additional insight.

\subsection{Public values and perceptions}

Demski et al. (2013) completed a nationally representative survey of the UK public. One of the questions they asked was to rank affordability, energy security and sustainability. Energy professionals were asked the same question and also how they perceive policymaker rankings. Those results are compared in Fig. 8.

The views and perceptions of energy professionals show a number of important similarities and differences. As Demski et al. (2013) point out; the importance ranking is closely linked to broader contextual issues, which mean comparison of such studies over time should be undertaken with caution (De Vaus, 2002).

The strong divergence in views highlights the potential for differ- ences in worldviews between general public opinion and the opinions of a highly knowledgeable public subset, as well as recognition of the challenges faced by policymakers. The findings suggest energy profes- sionals perceive views of policymakers to correspond to public views for affordability, at odds with their own priorities. Qualitative answers suggest energy professionals feel the public and policymakers fail to 


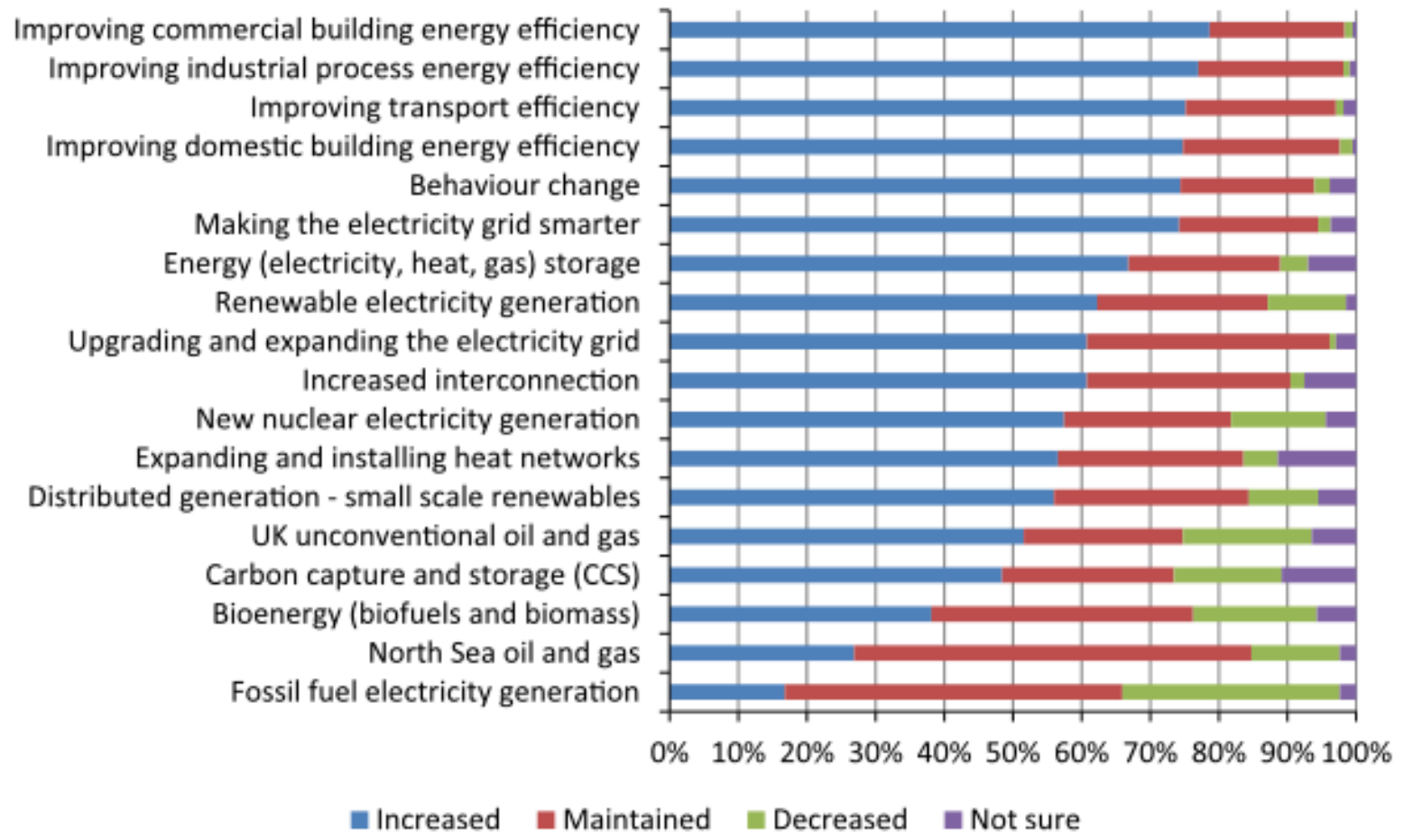

Fig. 7. Changes to investment levels.

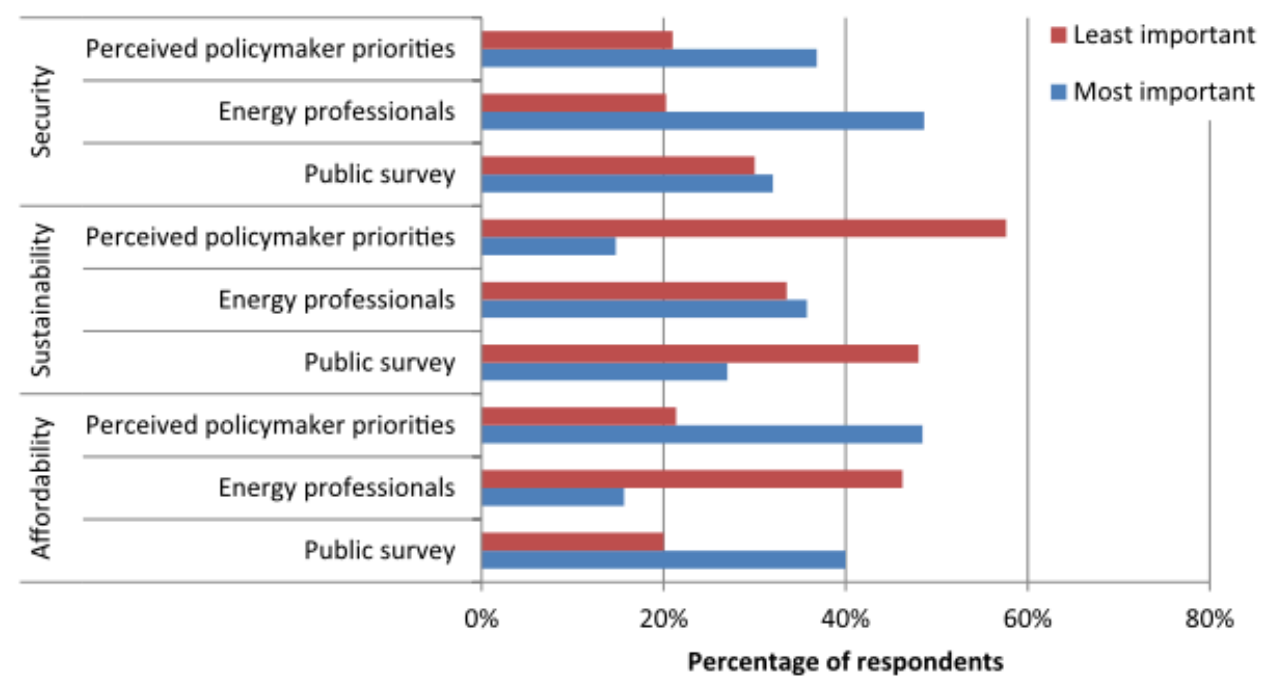

Fig. 8. Comparison of public, professional and perceived policymaker rankings for energy security, sustainability and affordability.

grasp the costs associated with energy provision, leading to unrealistic price expectations.

The findings for sustainability suggest professionals prioritise this differently to the public, and a majority particularly feel this is policymakers' least important factor. Qualitative responses suggest energy professionals are aware of their crucial role to meet this sustainability challenge, and wish to expedite this transition. Professionals think policymakers prioritise this less than even the public would like, which may engender support for enhanced sustain- ability policies.

Energy professionals believe policymakers are more closely aligned with their own views of energy security, suggesting they are confident policymakers understand the consequences of disruption to energy supply. This presents opportunities for policymakers and energy companies to rebuild lost 
trust (Butler et al., 2015). One particular example where energy professionals' views are in stark contrast to public opinion around support for nuclear power; seen by $57 \%$ of the former as requiring increased investment, but only highly favoured by $13 \%$ of the public (Parkhill et al., 2013). This is judged to be driven by energy professionals' prioritisation of energy security and obligation to 'keep the lights on', which makes nuclear an attractive option, despite concerns on affordability and sustainability grounds. Better under- standing of priorities for these different groups, particularly around energy security could lead to fuller, more honest debate.

\subsection{Energy Efficiency and energy storage}

The prominence of energy efficiency in the Energy Barometer is consistent with a study of energy strategies under uncertainty (Watson et al., 2014), which recognises the need to prioritise energy efficiency action in the short-term. This is corroborated by the EI's professional members, with efficiency appearing at or near the top of the list of responses relating to decarbonisation targets, investment and innova- tion.

Energy professionals identified energy storage as the area in great- est need of innovation (EI, 2015). This reflects a DNV (2015) survey, in which $>60 \%$ of its 1665 respondents placed changes to energy storage in their top three most important levers to integrate higher shares of renewables. Results for these two similar questions were collected in different ways. The DNV study provided respondents with a range of possible responses, who were asked to select up to three; Energy Barometer respondents were given free choice, with their answers being coded and consolidated. Table 7 shows the top ten highest responses to questions relating to changes to expedite change.

The colour coding in Table 5 demonstrates the similarities between these results, with four of the top five and six of the top ten identified

factors being similar in both cases. This suggests a level of coherence of understanding from energy professionals, as well as a strong recogni- tion and agreement of the potential for energy efficiency, storage, distributed generation and the requisite enabling grid infrastructure changes. This has important implications for policymakers, in terms of the areas they should prioritise to begin to deliver against targets for decarbonisation, as well as recognising the opportunity for the UK in global markets for these technologies and innovations.

\section{The role of the Energy Barometer in future energy scenario studies}

EI members were asked to consider decarbonisation technologies towards UK emission targets (Climate Change Act, 2008), specifically regarding potential of particular technologies by 2030. 2030 was selected, rather than 2050, as being a timescale within which new climate and energy frameworks must deliver structural change, and ties into pan-European energy infrastructure challenges (Gaventa, 2013). To answer this question, members were able to select potential low carbon technologies from a pre-defined list. The percentage contribu- tions of each category are calculated from the total number of selections (De Vaus, 2002). It is now possible to compare the results for particular renewable technologies with those projected by scenario studies such as Foxon (2013) and Spataru et al. (2015). The compar- ison with Foxon (2013) is selected as its electricity transition pathways are dominated by each of the stakeholder groups considered in this paper. Spataru et al. is selected due to its identification of two binary scenarios for 2030 with different properties covering energy and electricity supply, and comparisons with other electricity supply results. Three separate comparisons are therefore made with the Energy Barometer:

- Low carbon technology contributions to primary energy supply in 2030

- Low carbon technology contributions to 2030 electricity supply

- Policy uncertainty and investment risk 


\subsection{Energy supply}

The different ambitions for energy supply from low carbon tech- nologies (Spataru et al., 2015) can be compared with the Energy Barometer (EI, 2015) results of energy professionals' perceptions of energy technologies contributions to decarbonisation in 2030. Fig. 9 provides a schematic showing the calculation steps and assumptions used to compute the comparison for low carbon primary energy supply, applying energy professionals' views to technologies applied by Spataru

\begin{tabular}{|c|c|c|c|c|}
\hline \multirow[t]{2}{*}{$\begin{array}{l}\text { Which changes to } \\
\\
\text { Rank }\end{array}$} & \multicolumn{2}{|c|}{$\begin{array}{l}\text { echnology, } \\
\text { markets, behaviour and regulation do } \\
\text { you believe are most important in } \\
\text { your market(s) of interest for } \\
\text { integrating a high share of } \\
\text { renewables ( } 70 \% \text { by generation) in a } \\
\text { cost-effective and secure way? }\end{array}$} & \multicolumn{2}{|c|}{$\begin{array}{l}\text { Where in the energy system do you } \\
\text { think is the greatest need for } \\
\text { innovation? }\end{array}$} \\
\hline & $\begin{array}{l}\text { DNV Survey } \\
\text { Results }\end{array}$ & $\begin{array}{l}\text { Percentage of } \\
\text { respondents }(\%)\end{array}$ & $\begin{array}{l}\text { Energy } \\
\text { Barometer } \\
\text { results }\end{array}$ & $\begin{array}{l}\text { Number of } \\
\text { mentions }\end{array}$ \\
\hline 1 & Energy storage & 65.5 & Energy storage & 108 \\
\hline 2 & Smart prids & 41.2 & Nuclear energy & 43 \\
\hline 3 & $\begin{array}{l}\text { Investment in } \\
\text { new grid } \\
\text { infrastructure }\end{array}$ & 36.6 & Energy efficiency & 41 \\
\hline 4 & Energy efficiency & 35.1 & $\begin{array}{l}\text { Making the } \\
\text { electricity grid } \\
\text { smarter }\end{array}$ & 41 \\
\hline 5 & $\begin{array}{l}\text { Demand side } \\
\text { response }\end{array}$ & 27.7 & $\begin{array}{l}\text { Distributed } \\
\text { generation }\end{array}$ & 39 \\
\hline 6 & $\begin{array}{l}\text { Grid regulation } \\
\text { reforms }\end{array}$ & 25.5 & $\begin{array}{l}\text { Demand } \\
\text { management }\end{array}$ & 36 \\
\hline 7 & $\begin{array}{l}\text { Siting of } \\
\text { renewable } \\
\text { generation closer } \\
\text { to where it will } \\
\text { be consumed }\end{array}$ & 20.0 & $\begin{array}{l}\text { Carbon capture } \\
\text { and storage }\end{array}$ & 34 \\
\hline 8 & $\begin{array}{l}\text { Electrification of } \\
\text { transport }\end{array}$ & 18.5 & $\begin{array}{l}\text { Renewable } \\
\text { energy }\end{array}$ & 24 \\
\hline 9 & $\begin{array}{l}\text { Day-ahead and } \\
\text { real time energy } \\
\text { markets }\end{array}$ & 13.8 & $\begin{array}{l}\text { Renewables - } \\
\text { marine }\end{array}$ & 24 \\
\hline 10 & Capacity markets & 13.8 & $\begin{array}{l}\text { Upgrading and } \\
\text { expanding the } \\
\text { electricity grid }\end{array}$ & 24 \\
\hline
\end{tabular}

et al. (2015).The comparison in Fig. 10 shows, against K- and Z-scenarios,

energy professionals see solar energy contributing a larger amount that the projections, whereas nuclear projections, particularly for the Z- scenario are more closely aligned with the views of energy profes- sionals. Professionals' views of wind's potential impact are slightly lower than the comparative scenarios. This comparison would certainly suggest the considerable differences in solar contributions between projections and energy professional views is worthy of further explora- tion. DECC (2015) anticipate reaching 12-14 GW of solar deployment by 2020 , which would appear to corroborate the energy professionals' views, although a more detailed assessment would be required to understand the implications of such a change on the 2030 energy system scenarios. 


\subsection{Electricity supply}

Compared across a range of studies, the UK's total electricity supply for 2030 is projected to be 350 720 TWh (Foxon, 2013; Spataru et al., 2015). Studies of electricity in 2030 are particularly relevant due to the Committee on Climate Change (CCC) recommendations to largely decarbonise the electricity system by 2030 (CCC, 2013). Where such studies provide a breakdown by technology, it is possible to compare them against energy professionals' technology perspectives. CCS tech- nology is specifically modelled for electricity generation in Foxon (2013) and Spataru et al. (2015) and therefore included as a con- tributor to electricity supply. Wind energy is separated into onshore and offshore contributions. One challenge for such studies is the selection and categorisation of different technologies. To address such differences, a comparison is undertaken across the scenarios, before a range of more mainstream low carbon technologies present in Spataru et al. (Fig. 6, 2015) is reconsidered. The mainstream technologies are defined as being present across all scenarios, providing significant contributions to decarbonisation, as well as being identified by energy professionals as important and, in most cases, uncertain.

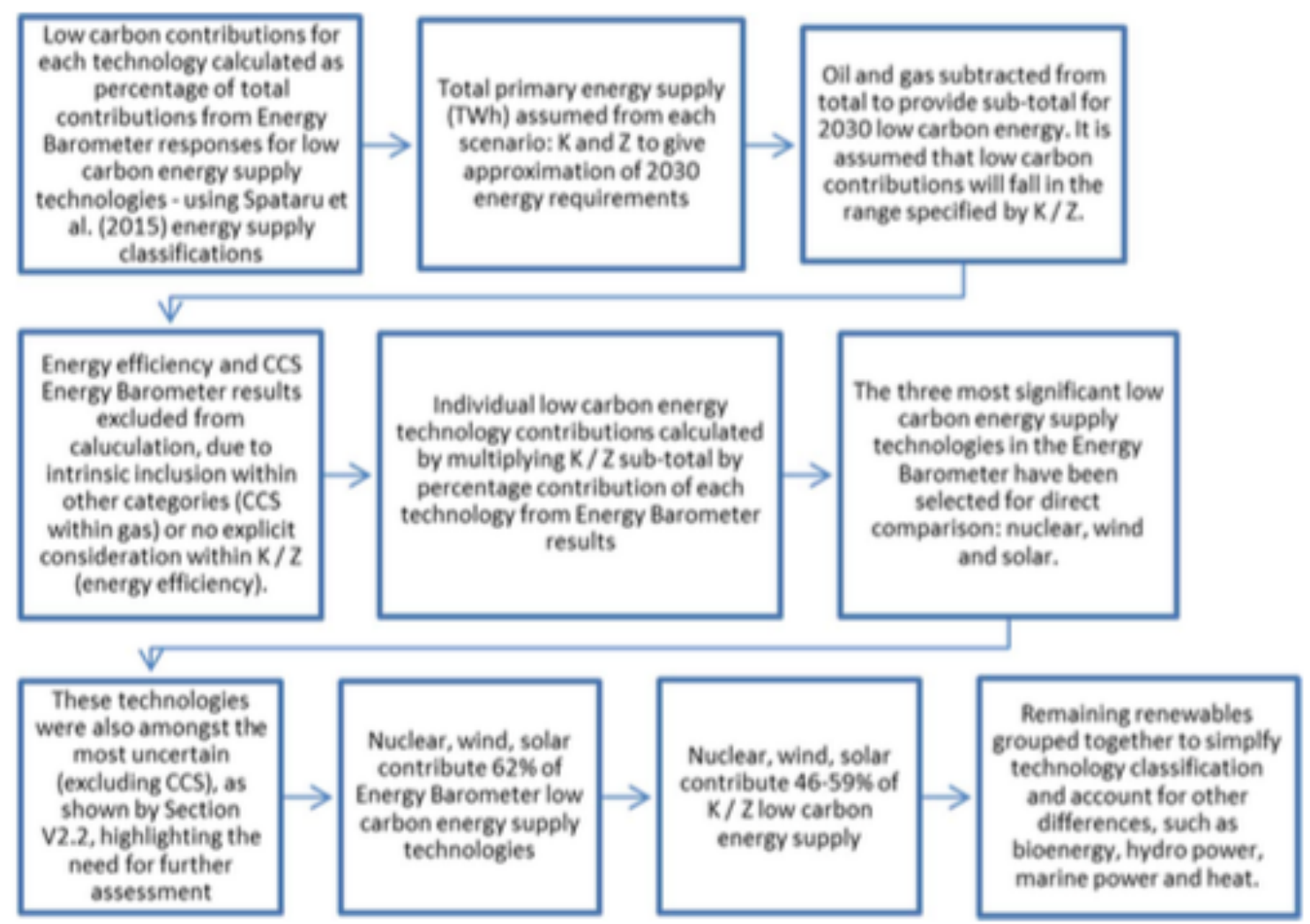

Fig. 9. Schematic and computational steps for comparison with energy supply scenario study.

\subsubsection{Comparison across scenarios}

Fig. 11 illustrates the computations and assumptions used to compare electricity supply scenarios with Energy Barometer results.

This comparison of electricity supply scenarios demonstrates that a number of core supply technologies (nuclear, wind and CCS) contribute $50-90 \%$ of electricity supplied across the different scenarios. Interestingly, the views of energy professionals tend to most closely align with the civil society-led pathway - Thousand flowers, with similar contributions from CCS, onshore and offshore wind, as well as similar contributions from the 'other' categories overall. The views of energy professionals differ significantly from all scenarios for solar power and electricity storage. This alludes to the potential energy professionals see for a decentralised energy system. Another observa- 
tion is the positive response to all technologies presented to energy professionals, suggesting the need for follow-up work to analyse the 'other' technologies in greater detail to highlight particular trends within less mainstream options. Whilst it is useful to compare the K-Z-Scenarios in this manner, the predilection towards the mainstream options, presents an opportunity for a more direct comparison with a sub-set of energy professionals' preferences. It should be noted that whilst the level of CCS is now unlikely to be seen, given a change in UK government policy (Carrington, 2015), at the time of research, this was in keeping with policy for CCS to 'be commercial within a decade' (DECC, 2014) (Fig. 12).

\subsubsection{Comparison of mainstream low carbon electricity supply technologies}

Fig. 13 illustrates the computations and assumptions used to compare electricity supply technologies present in Spataru et al. (Fig. 6, 2015) with energy professionals perspectives. (Fig. 14).

Energy professionals' perception of CCS potential is more closely aligned to K-scenario, as would be expected, given the prominence in this scenario for CCS. This highlights the expectation placed by energy professionals on this currently unproven technology in order to meet long term climate targets. The main differences appear as a result of the energy professionals' belief in the potential of nuclear electricity which is $2-4$ times the contribution projected in the K-Z scenarios. The other area of clear disagreement between the scenarios and professionals is on offshore wind, with professionals placing significantly less expecta- tion on this technology than either of the modelled scenarios. This may be explained by their desire to include a wider range of technologies in the electricity mix, however, it may also suggest professionals are yet to be convinced offshore wind will deliver the supply security they expect. This is a challenge for the offshore wind industry and its stakeholders. 


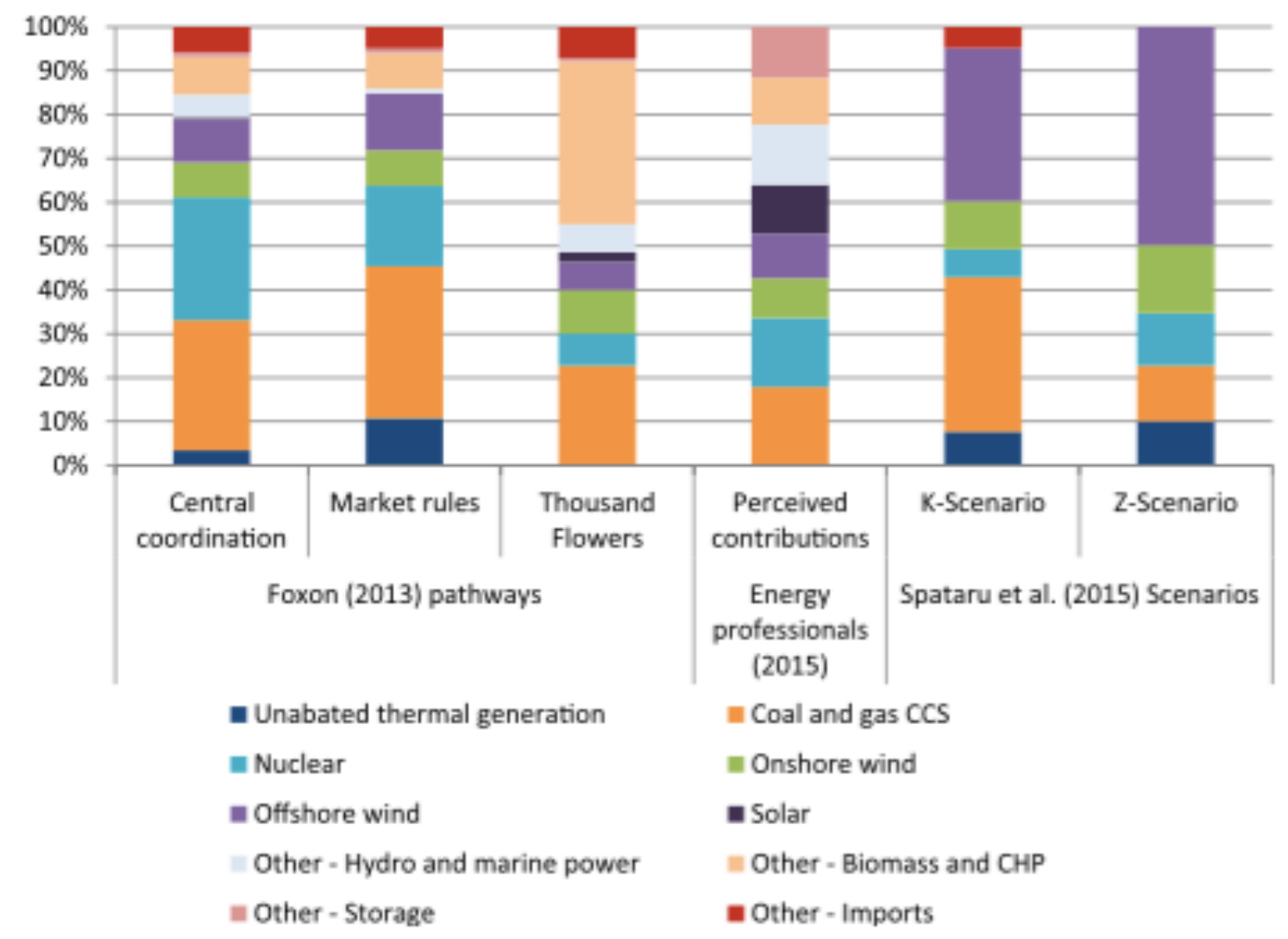

Fig. 12. Comparison of 2030 technology contributions across scenarios.

Other Energy Barometer results hint at a solution, in the extremely high proportion of members alluding to the potential of both energy efficiency and storage demand-side measures, which would reduce the disruption caused by wind intermittency. Energy efficiency is assumed within the energy demand input assumptions by Spataru et al. (2015); however, it is not clear how the views of energy professionals, who state energy efficiency improvements as having the highest overall potential to contribute to decarbonisation, can be factored into scenario studies. This is an area that requires further investigation to ensure such demand-side opportunities are effectively factored into scenario mod- elling (Hinton and Thumim, 2014).

\subsection{Policy uncertainty and investment risk}

As previously identified, the CCC recommends the decarbonisation of the electricity sector by 2030 . Scenarios compared by Spataru et al. (2015), provide different suggestions as to the total electricity supply

requirements in 2030. Energy professionals' perceptions of technology potential, combined with their views on investment risk and policy uncertainty can be considered to identify opportunities for both the industry and policymakers.

Building upon V.1, V.2 and results for energy storage and decen- tralised generation, it is possible to examine how electricity supply would be met in various scenarios, assuming complete electricity decarbonisation in 2030 and the proportional contributions of poten- tial electricity technologies, based on the views of energy professionals.

Fig. 15 provides energy professionals' perspectives of individual technologies, showing a range of scenarios for electricity supply and comparing them to professionals' perception of investment risk due to policy uncertainty. Fig. 16 illustrates the computations and assump- tions used to allocate 
electricity supply from low carbon sources with Energy Barometer results across a range of scenarios, assuming electricity decarbonisation by 2030 .

K- and Z-scenarios provide the central range, with outlying scenarios provided by Friends of the Earth - 'Good Scenarios' (FOE, 2006) and UK Government - Zeta (2010). Spataru et al. (2015) provide an in depth comparison of differences between these scenarios included here to illustrate the projected range of electricity supplies. Comparing this potential against the investment risk due to policy uncertainty provides useful insights into energy professionals' perspec- tives of risk and reward for different technologies. CCS is seen as a high potential technology for 2030 with very high risk, with onshore wind regarded in a similar light. Nuclear, energy storage and solar power are all seen as high potential technologies with current policy conditions favouring investment in these areas. Offshore wind is considered slightly higher risk, for potentially lower overall reward in terms of decarbonised supplied electricity. Through a longitudinal comparison of these two short-term (current) and medium-term (15 years) measures across scenarios, a greater understanding of the expectations for investment can be developed.

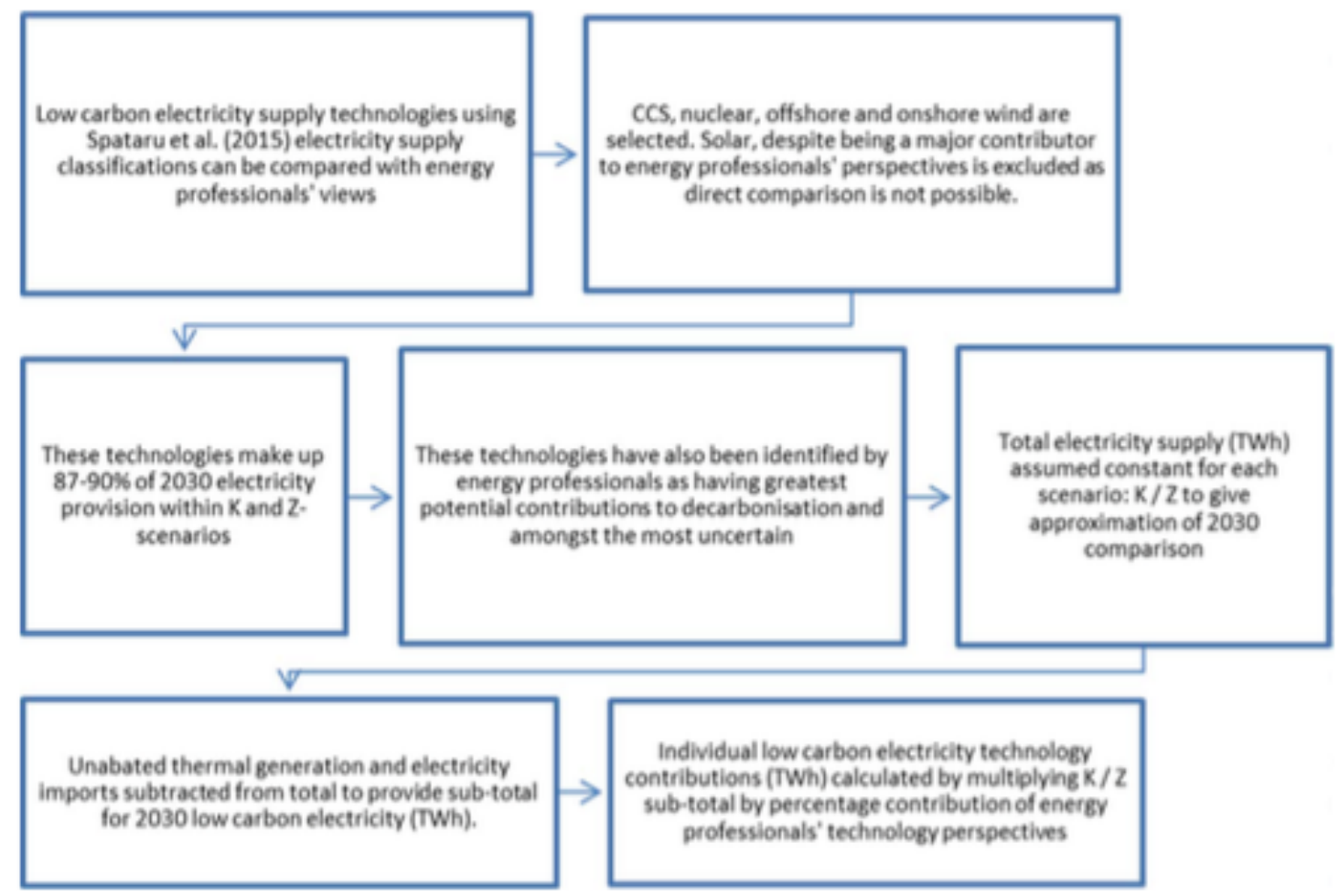

Fig. 13. Schematic and computational steps for comparison with electricity supply scenario study.

6. Conclusions and policy implications

6.1. Implications of these results for scenarios studies and link with academia

The Energy Barometer presents an opportunity to compare aca- demic studies with representative views of professionals, which can have an effect on academic assumptions around particular technologies, augment Delphi and other exploratory assessments, and provide additional insight into deployment preferences of experienced practi- tioners.

Foxon (2013) recognises the political and economic challenges for energy companies as high levels of investment are required in a range of low carbon generation technologies. The importance of these challenges to energy professionals are recognised throughout the Energy Barometer results. This is acknowledged in the need for clear, coherent and stable energy policy, seen as the number one challenge for the energy industry in 2015 , combined with increased investment risk due to policy 
uncertainty, over the previous 12 months, in most low carbon generation technologies and a call for increased investment in most sectors, but particularly energy efficiency. By tracking such sentiments, these may help shape underlying scenario assumptions.

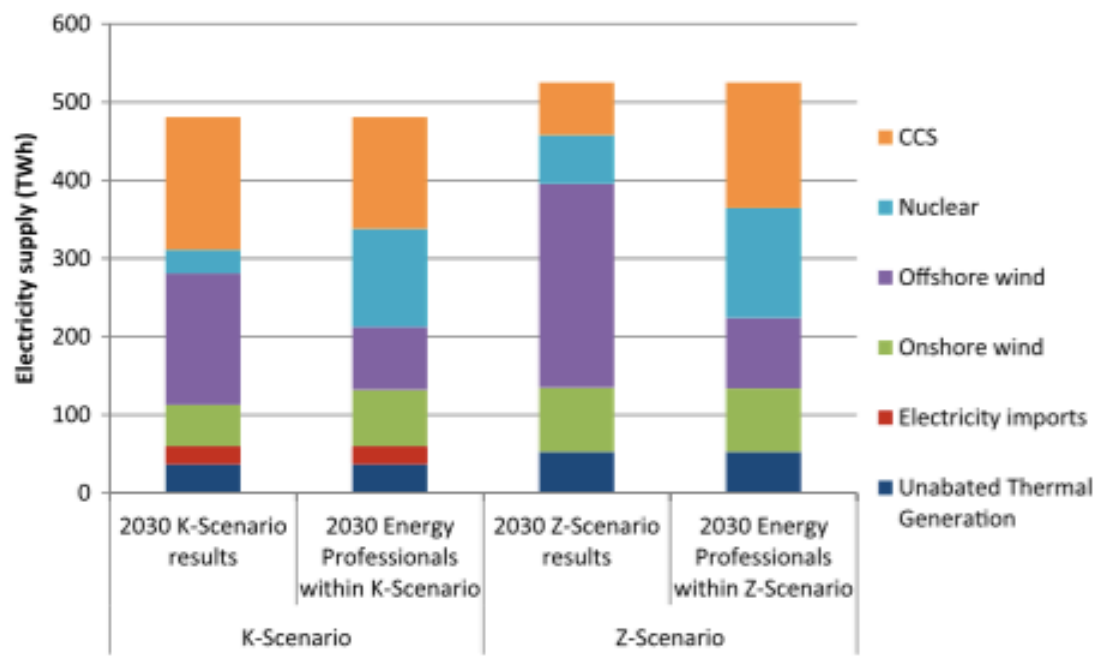

Fig. 14. Comparison of energy professionals' perception of low carbon electricity supply technology potential with electricity supply scenario studies.

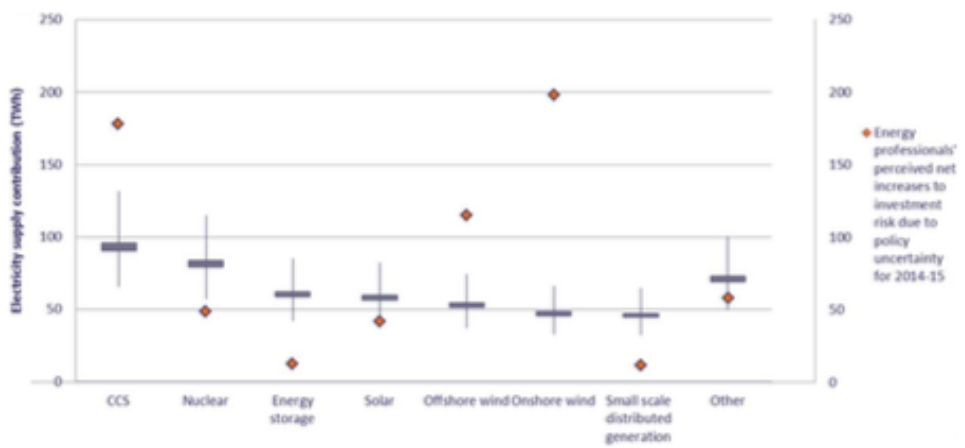

Fig. 15. Energy professionals' perceived technology contributions by 2030 for K-Scenario, Z-Soenario, and outlying scenarios compared with perceived increase or decrease in investment risk due to policy uncertainty for 2014-2015.

The implication of this work for social studies of energy issues is to deliver a dataset and robust mechanism to compare the views and priorities of energy professionals with those of the general public. In a similar manner to the identification of suitable and acceptable solu- tions, this enables dialogue to be established to identify and understand differences and similarities between stakeholder groups. One tangible implication relates to the work of Rogers-Hayden et al. (2011), examining UK energy discourses, whose findings suggested the domi- nant discourses were of climate change as an environmental issue and energy security as a an energy supply crisis, inevitably necessitating significant nuclear investment. Whilst the Energy Barometer results suggest that nuclear support amongst energy professionals continues to be high, there also appears a strong call for consideration of other technologies, notably energy efficiency and energy storage. This implies a departure towards the counter-hegemonic discourse identified by Rogers-Hayden et al. (2011), in which climate change requires societal change through reduced energy demand and greater energy supply diversity.

\subsection{Policy implications}

Energy professionals recognise policy continuity and the need for long-term, holistic approaches to 
energy policy are critical for sustained investment and propagation of energy technologies (EI, 2015). This paper provides insight into changes in professional opinion regarding energy issues, priorities and contentious topics. By extension from cross-sectional to longitudinal study, the methodology presented here- in can provide recurring, timely insight.

This 2015 study assesses perceived changes to investment risk due to policy uncertainty during the last year of the UK's 2010-2015 coalition government. With ongoing implications for policymaker engagement with professionals to reduce such uncertainty and there- fore encourage investment, the methodology presents an opportunity to provide a similar assessment in 2016 of the first year of the new government.

Results show the importance of policymakers delivering transpar- ent, consistent and stable policy frameworks to achieve the UK's long- term climate targets. Consensus from professionals working across the sector identifies energy efficiency as an area for far greater coordina- tion, engagement and investment and provide strong platforms for policy action.

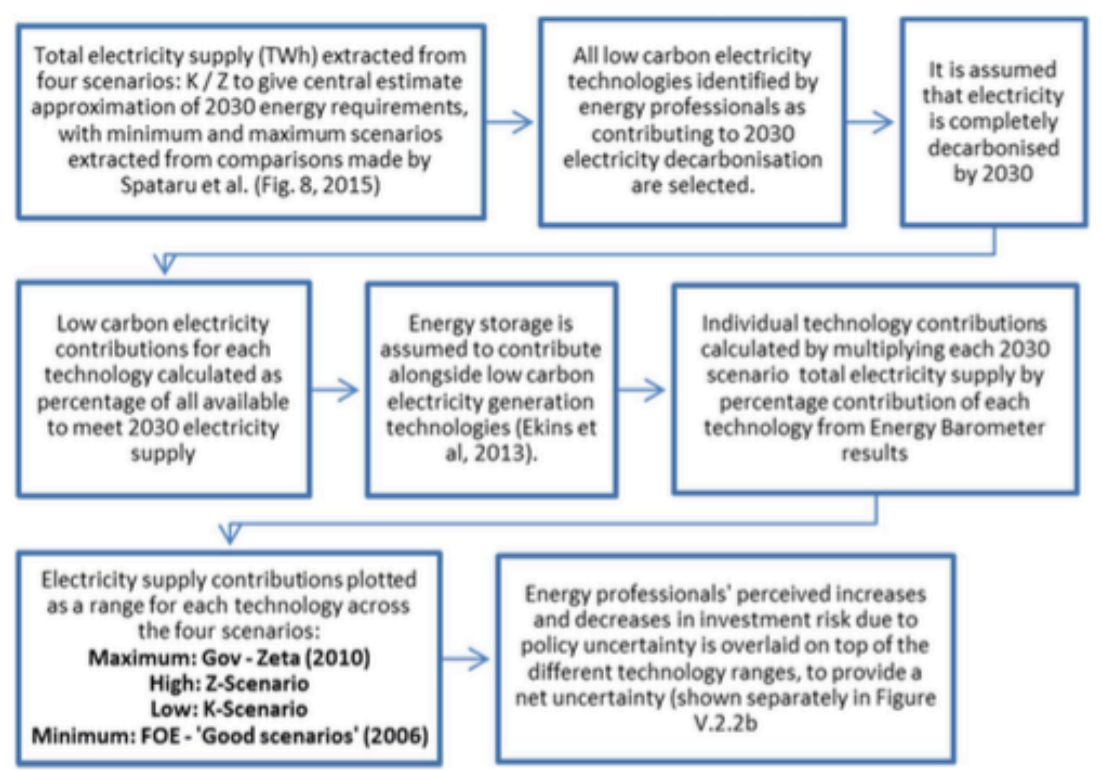

Fig. 16. Schematic and computational steps for comparison across multiple electricity supply scenarios and consideration of investment risk due to policy uncertainty.

168

Another implication for policymakers is the need to provide clarity and reduce uncertainty around large scale power generation, particu- larly wind, nuclear and CCS. With government and policymakers encouraged to unlock investment to large-scale, high-cost capital investments.

\subsection{Reflections for methodology development}

The 543 responses collected from this survey have generated a representative sample of the EI's energy professionals, with a high response rate for email surveys. All respondents are members of the EI based in the UK, and so their perceptions reflect the UK's energy system. However, it cannot be said this research is truly representative of all energy professionals, with both the total population and defini- tion of energy professionals being uncertain, outside of the EI's own parameters. Coverage was achieved for the total population of EI energy professionals, although the weighting of different groups has not been considered. The views of EI Fellows (FEIs) have been given greater prominence in the study, given the responses from this group as a proportion of the greater population. Given the nature of the survey in gathering perspectives of experienced energy professionals, a bias towards those with greater experience is considered a benefit. However, this should be further explored to analyse data beyond the level of energy professionals to, for example, consider differences between 
the views of Fellows and Graduates to identify generational shifts in professionals' views.

The findings and field experience demonstrate the value of the two- stage survey completion process, achieving significantly higher re- sponse rates than those typically expected for online surveys. De Vaus (2002) reveals that true replication is difficult for social surveys, due to the time and circumstance of two surveys enabling researchers to defend different results. Whilst this standalone research falls into that trap, every effort has been made to establish a balance between a replicable annual survey and a collection of views across the whole population of EI professional members.

Due to the compulsory nature of many questions, the quantity of data collected is high, with 543 completed questionnaires. The qualitative questions also had high completion rates (400+ responses), requiring only minimal and straightforward data cleansing, which contributed to high quality data. To ensure this quality, several questions included a 'not sure' option, which was rarely used.

Additionally, respondents were asked to provide a subjective assess- ment of their knowledge of each subject area in turn. Whilst there are limitations of such a subjective approach, such as it being more a measure of confidence than knowledge, it does provide the opportunity to compare results between individuals to check data quality.

Question order can influence responses and therefore the accuracy of the findings, which is a concern for qualitative questions with free- text responses. However, the broad range of subjects covered and level of detail presented as well as number of responses to this optional question act to minimise such effects and provide a level of credibility to the results. Future Energy Barometer questionnaires could randomise question order to identify the possible impact of this effect.

\subsection{Concluding remarks}

This paper demonstrates a number of areas in which the views of energy professionals corroborate existing research, as well as identify- ing new opportunities for further collaboration with and investigation of the opinions, views and values of this important stakeholder group. In particular, there are three notable achievements:

a) Cross industry participation and engagement - oil and gas, power generation and demand management professionals, envir- onmentalists, engineers, business managers and consultants have all contributed to make this a comprehensive study.

b) Opportunities for dialogue - these findings provide a platform for two-way information exchange within a broad conversation across overlapping stakeholder groups. This research enables those with strong technical knowledge and understanding to feed into what Whitmarsh (2011) describe as a collective "reservoir of knowledge" to help shed light on whether and how energy technologies will be used, as well as opening up and extending peer review by demonstrating that there are differences of opinion around the certainty and risk for specific technologies.

c) Arriving at consensus - energy professionals agree on the importance of policy continuity, additional energy efficiency mea- sures and the need for greater energy system investment. Whilst these challenges are anecdotally well understood by professionals, the Energy Barometer provides a collective voice on priority issues.

Acknowledgements

This research was carried out in collaboration with the Energy Institute. The authors would like to thank Sarah Gregory, Deane Somerville and Martin Maeso of the Energy Institute for their comments on earlier drafts, and all of the research participants. We also thank the EI's Energy Advisory Panel and Dimitrios Xenias of Cardiff University for their support with the questionnaire development. 


\section{References}

Balta-Ozkan, N., Watson, T., Connor, P., Axon, C., Whitmarsh, L.E., Davidson, R., Spence, A., Baker, P., Xenias, D., Cipcigan, L.M. and Taylor, G., 2014. Scenarios for the Development of Smart Grids in the UK: synthesis report. [Project Report]. London: UKERC

Blyth, W., McCarthy, R., Gross, R., 2015. Financing the UK power sector: Is the money available? Energy Policy 87, 607-622.

Butler, C., Demski, C., Parkhill, K., Pidgeon, N., Spence, A., 2015. Public values for energy futures: Framing, indeterminacy and policy making. Energy Policy 87, 665-672.

Capstick, B., Demski, C., Sposato, R., Pidgeon, N., Spence, A., Corner, A., 2015. Working Paper - Public perceptions of climate change in Britain following the winter 2013/ 2014 flooding. Cardiff: Understanding Risk Research Group

Carrington, D., 2015. UK cancels £1bn pioneering carbon capture and storage competition. 25 November 2015. [News]Available at: < https://www theguardian. com/environment/2015/nov/25/uk-cancels-pioneering-1bn-carbon-capture-and- storage-competition $\rangle$ (accessed on 27.6.2016).

Charmaz, K., Smith, J., 2010. Grounded theory. International Encyclopaedia of Education. Elsevier, 406-412.

Climate Change Act, 2008. (Chapter 27). London: The Stationery Office.Committee on Climate Change, 2013. Next steps on Electricity Market Reform - securing the benefits of low-carbon investment. Committee on Climate Change, London.

Demski, C., Spence, A., Pidgeon, N., 2013. Transforming the UK energy system: Public values, attitudes and acceptability - Summary findings from a survey conducted August 2012. London: UKERC.Department of Energy and Climate Change (DECC), 2012. The Energy Efficiency Strategy: the Energy Efficiency Opportunity in the UK. Department of Energy and

Climate Change, London.Department of Energy and Climate Change (DECC), 2014. Next steps in CCS: developing an approach for the next phase of CCS projects in the UK. Department of Energy and

Climate Change, London.Department of Energy and Climate Change (DECC), 2015. Delivering UK energy investment: low carbon energy. Department of Energy and Climate Change, London. De Vaus, D., 2002. Surveys in Social Research 5th edn. Routledge, Abingdon.DNV, 2015. Beyond integration: Three dynamics shaping renewables and the grid. Available at: <

https://www.dnvgl.com/energy/publications/download/beyond integration.html $\rangle$ (accessed on 27 August 2015).

E.ON UK, 2008. E.ON launches Energy Manifesto Carbon, Cost and Consequences, calls for open and honest debate on UK energy needs. 3 June 2008. Available at: 〈http:// pressreleases.eon-uk.com/blogs/eonukpressreleases/archive/2008/06/03/1229. aspx 〉 (accessed $25.08 .15)$.

Energy Institute (EI), 2015a. Energy Barometer 2015: views from UK energy professionals. Energy Institute, London.

Engineering and Physical Sciences Research Council (EPSRC), 2015. Introduction to the college. Available at: https://www.epsrc.ac.uk/funding/assessmentprocess/college/ intro/) (accessed 27.08.15).

Fink, A., 2013. How to conduct surveys: A step-by-step guide 5th edn. Sage, London. Foxon, T., 2013. Transition pathways for a UK low carbon electricity future. Energy

Policy. 52, 10-24.Gaventa, J., 2013. Infrastructure networks and the 2030 climate and energy framework. London: E3G.Gill, J., Johnson, P., 2010. Research Methods for Managers 4th edn. Sage, London. Groves, R., Fowler, F., Couper, M., Lepkowski, J., Singer, E., Tourangeau, R., 2009.

Survey methodology. Wiley, Hoboken.Hinton, T., Thumim, J., 2014. An analysis of D3 in DECC's energy system models.

Centre for Sustainable Energy, Bristol.HM Government, 2011. Carbon Plan. HM Government, London.Ipsos Mori, 2009. Energy Issues 2009: survey of British public opinion. IpsosMori,

London.Ipsos Mori, 2015. Issues Index June 2015. IpsosMori, London.Jefferies, I., 2012. Energy efficiency trends report. EEVS Insight Ltd., London. Kearnes, M., Wynne, B., 2007. On nanotechnology and Ambivalence: the Politics of

Enthusiasm. NanoEthics 1, 131-142.Morgan, D., 2007. Paradigms lost and pragmatism regained: Methodological implications of combining qualitative and quantitative methods. J. Mixed Methods Res. 1, 48-76.Parkhill, K., Demski, C., Butler, C., Spence, A., Pidgeon, N., 2013. Transforming the UK energy system: public values, attitudes and acceptability - Synthesis report. UKERC,

London.Pollitt, M., Shaorshadze, I., 2011. The Role of Behavioural Economics in Energy and

Climate Policy. Available at: 〈http://www.eprg.group.cam.ac.uk/wp-content/ uploads/2014/01/EPRG1130_Main.pdf〉 (accessed on 27 
August 2015).

Rogers-Hayden, T., Hatton, F., Lorenzoni, I., 2011. "Energy security" and "climate change": Constructing UK energy discursive realities. Glob. Environ. Change 21 (1), 134-142.Saunders, M., Lewis, P., Thornhill, A., 2012. Research Methods for Business Students 6th edn. Pearson, Harlow.Shankleman, J., 2015. Who killed the Green Deal?7 August 2015 [Blog]Available at: (http://www.businessgreen.com/bg/analysis/2421068/who-killed-the-green-deal (accessed 25.08.15).

Spataru, C., Drummond, P., Zafeiratou, E., Barrett, M., 2015. Long-term scenarios for reaching climate targets and energy security in UK. Sustain. Cities Soc. 17, 95-109.

Turner, A., 2011. Proposals for the Green Deal / Energy Company Obligation. Committee on Climate Change, London.

Usher, W., Strachan, N., 2012. Critical mid-term uncertainties in long-term decarbonisation pathways. Energy Policy 41, 433-444.Watson, J., Gross, R., Ketsopoulou, I., Winskel, M., 2014. UK energy strategies under uncertainty - Synthesis Report. UKERC, London.

West, J., Bailey, I., Winter, M., 2010. Renewable energy policy and public perceptions of renewable energy: a cultural theory approach. Energy Policy 38, 5739-5748. Whitmarsh, L., 2011. Scepticism and uncertainty about climate change: dimensions, determinants and change over time. Glob. Environ. Change 21, 690-700. 